\title{
THE AUDITOR'S REPORT
}

To the Council and Members of the

Fauna Preservation Society.

17th February, 1960.

Accounts for the Year ended 31st December, 1959

We have completed the audit of the Books and Accounts of the Society for the year ended 31st December, 1959, and report thereon as follows :-

\section{General Purposes Account}

The Balance on this account at the end of the year was $\mathfrak{3 , 8 1 7} 2 s$. after transferring $£ 30$ from the Life Membership Fund and deducting $\mathfrak{1 5 3} 11 \mathrm{~s}$. 10d. being the excess of Expenditure over Income on the year's working.

The excess of expenditure over income in the previous year was $£ 5014 s .1 d$.

Claims for repayment of Income Tax deducted under Deeds of Covenant have now been admitted, as the appeal to the Special Commissioners of Income Tax, referred to in last year's Report, was successful.

Number of Members and Arrears of Subscriptions

The number of Members on the Roll at 31st December, 1959, was 1,799 , made up as follows :-

$\begin{array}{lrr}\text { Honorary Members : } & \text {. } & \mathbf{1 5} \\ \text { Life Members } & \cdot & \mathbf{3 6 1} \\ \text { Ordinary Members } & \cdot & 1,423 \\ & & 1,799\end{array}$

This shows increases of 78 Life Members and 270 Ordinary Members.

At 31st December, 1959, there were 81 Members in arrear with their Subscriptions.

\section{General Reserve Fund}

A further sum of $\mathfrak{4} 4,4353 s$. $8 d$. has been placed to reserve which represents the amount of the donations and legacy received during the year. The balance on the Fund at 31st December, 1959, was $£ 9,3574 s$. 


\section{Life Membership Fund}

The balance standing to the credit of the Fund is now $£ 4,610$. This is after crediting $£ 1,260$ in respect of Life Membership subscriptions received during the year and transferring $£ 30$ to the General Purposes Account which represents the value of subscriptions of those Life Members whose membership ceased during the year.

\section{INVESTMENTS}

The total investments at 31st December, 1959, at Cost amounted to $£ 13,1373 s$. $11 d$., and the Market Value at that date was $£ 15,35311 s .6 d$., showing a net appreciation of $£ 2,2167 s .7 d$.

The increase in the Bank balance is accounted for by the legacy of $\$ 11,000$ (approximately $\$ 4,000$ ) from the late Dr. Van Name, being received late in December. This amount has since been invested.

\section{Surplus}

The surplus of Assets over Liabilities at the end of the year amounted to $£ 17,7846 s$., as compared with $£ 12,241$ 15s. $1 d$. at the end of the previous year.

\section{"Operation Noah" \\ Kariba Fund}

We have examined the transactions relating to this Fund, and annexed to the Society's Accounts is the Receipts and Payments Account for the nine months to 31st December, 1959, from which it will be seen that donations totalling $£ 11,45116 s .1 d$. have been received.

Payments to the Game Preservation and Hunting Association of Northern Rhodesia amounted to $£ 10,500$.

After deducting $£ 50819 s .9 d$. expenses, there is a cash balance remaining of $£ 44216 s$. $4 d$.

W. B. KEEN \& Co.

Chartered Accountants. 


\section{EXPENDITURE}

1958

\&

604

876

245

64

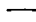

126

164

5

100

42

" Expenses in connection with International Meetings-

Copenhagen-Oil Pollution

- "Uganda Game Research-Grant

- " Rhinoceros Survey-E. P. Gee
"Office Expenses, Insurance Stamps, etc.

"Postage, etc.

"Maintenance of Films .

"Assistant Secretary's Pension-Premium ", Accountancy and Audit-

Audit Fee, 1959

Accountancy, 1959 . . . .

Income Tax Appeal and Repayment

, Subscriptions and Donations-

British Committee for International Nature Conservation . . .

International Committee for Bird Preservation . . .
GENERAL PURPOSES

\& s. d. \& s. $d$ $\begin{array}{lll}757 & 5 & 0\end{array}$

$\begin{array}{lll}1,071 & 5 & 9\end{array}$

$\begin{array}{lll}172 & 11 & 1\end{array}$

$\begin{array}{lll}140 & 6 & 8\end{array}$

$250 \quad 0 \quad 0$

25000

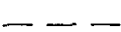

$\begin{array}{llllll}37 & 10 & 0 & 37 & 10 & 0\end{array}$

206112

$\begin{array}{lll}197 & 8 & 4\end{array}$

$\begin{array}{lll}10 & 3 & 0\end{array}$

$100 \quad 0 \quad 0$

15150

2100

$\begin{array}{llllll}57 & 15 & 0 & 94 & 10 & 0\end{array}$
$20 \quad 0 \quad 0$

$5 \quad 56$

$\begin{array}{llllll}1 & 0 & 0 & 26 & 5 & 0\end{array}$ 
for the year ended 31st DECEMBER, 1959

\section{ACCOUNT}

958.

$£ \quad £$

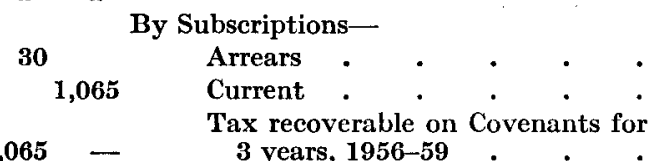

1,065

558 Donations and Legacies

$-\mathbf{5 5 8}$

547

75

351

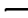

501

INCOME

Interest on Investments (Gross) .

Sundry Sales-Christmas Cards Service Commission) . . .

Balance-Excess of Expenditure over

Income for year carried to Balance
\& s. d. \& s. d.

444 $11 \quad 9$

$\begin{array}{lll}1,345 & 7 & 0\end{array}$

$\begin{array}{lllllll}577 & 10 & 1 & 1,967 & 8 & 10\end{array}$

$\begin{array}{lll}4.435 & 3 & 8\end{array}$

Less'Transfer to General Reserve Fund $\begin{array}{llll}4,435 & 3 & 8\end{array}$

$\begin{array}{lll}534 & 9 & 0\end{array}$

102211

$\begin{array}{llll}204 & 14 & 5\end{array}$

143150

1531110 


\section{LIABILITIES}

1958.

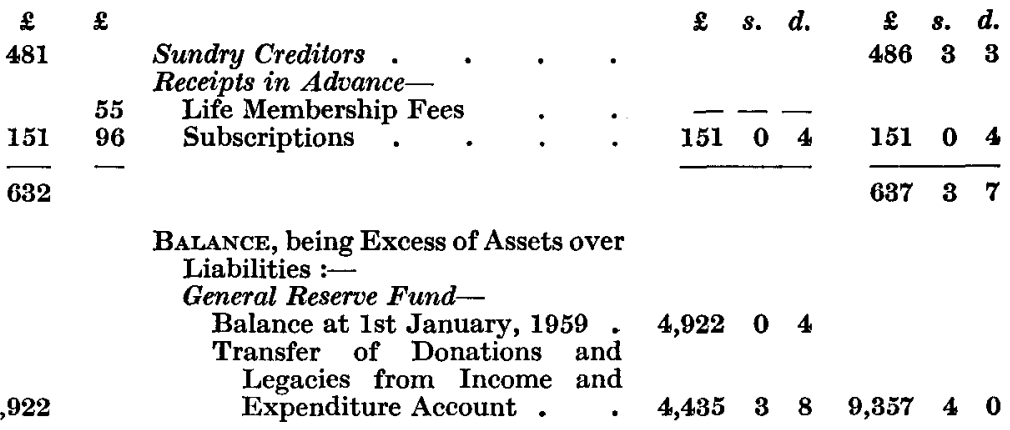

\section{Life Membership Fund-}

Balance at 1st

January, 1959 . $3,380 \quad 0 \quad 0$

Add Fees received $\begin{array}{llllllll}\text { during year } & \cdot & 1,260 & 0 & 0 & 4,640 & 0 & 0\end{array}$

Deduct Transfer to General Purposes Account-

Subscriptions of deceased Life

Members .

$$
\begin{array}{llllll}
30 & 0 & 0 & 4,610 & 0 & 0
\end{array}
$$

General Purposes Account--

4,371 Balance at 1st January, 1959 . Add Transfer from Life Membership Fund . Investments : $\begin{array}{lll}30 & 0 & 0\end{array}$ Sale of Fraction..

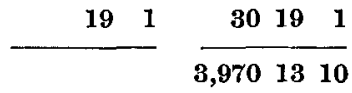

Deduct Excess of Expenditure

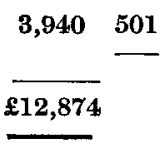
over Income for the year

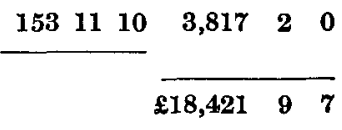

We have examined the above Balance Sheet and the accompanying Income and Expenditure Account with the books and Accounts of the Society and certify them to be in accordance therewith. We have verified the Bank Balance and the Investments of the various Funds.

Finsbury Circus House, W. B. KEEN \& CO.,

Blomfield Street,

Losdon, E.C. 2.

17th February, 1960 
1958.

Assets

里

Sundry Debtors-

$\mathbf{3 4 7}$

52

225

12,175
Income Tax Recoverable $\quad . \quad$. $\quad . \quad 69411 \quad 5$

$\begin{array}{llllll}121 & 13 & 7 & 816 & 5 & 0\end{array}$

Stock of Christmas Cards in Hand (at or under Cost) . . . . .

1371410

Investments (at Cost) :-

$\$ 3,960$ 11s. 5d. Conversion $3 \frac{1}{2} \%$ Stock . $3,604 \quad 1 \quad 5$

$£ 5253 \%$ Savings Bonds 1965-75 $\quad$ 525 0 0

$\$ 229 \mathrm{rs} .8 d$. Consols $2 \frac{1}{2} \% \quad$. $\quad . \quad . \quad 177002$

$£ 1,724$ 19s. 2d. $2 \frac{1}{2} \%$ Savings Bonds

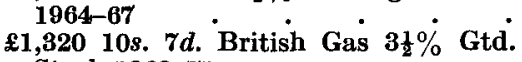

Stock 1969-71 ${ }^{\circ}$.

$£ 266$ 10s. British American Tobacco Co.,

Ltd. Ordinary Stock (10s. Units) .

$£ 1,452$ Thomas Firth and John Brown,

Ltd. \&1 Ordinary Shares .

$£ 275$ Shell Transport and Trading Co.,

Ltd. Ordinary Stock (Registered) .

$£ 290$ Associated Electrical Industries

Ordinary Stock . ${ }_{£ 37 \text { 10s. Pearl Assurance Co., Ltd. }}$

Ordinary Stock (5s. Units) . .

(Market Value at 31st December, 1959 : 215,354.)

Batance at Bank and Cash in Hand-

General Account

$\begin{array}{lll}1,602 & 6 & 8\end{array}$

1,2201511

$\begin{array}{lll}1,138 & 8 & 6\end{array}$

$1,450 \quad 106$

$\begin{array}{lll}1,461 & 8 & 6\end{array}$

$\begin{array}{lll}995 & 3 & 3\end{array}$

$\begin{array}{llllll}962 & 9 & 0 & 13,137 & 3 & 11\end{array}$

Petty Cash Accoun
$4,320 \quad 9 \quad 5$

$\begin{array}{llllll}9 & 16 & 5 & 4,330 & 5 & 10\end{array}$ 


\section{" OPERATION NOAH "-KARIBA FUND}

\section{RECEIPTS AND PAYMENTS ACCOUNT}

FOR THE 9 MONTHS TO 31ST DeCEMBER, 1959

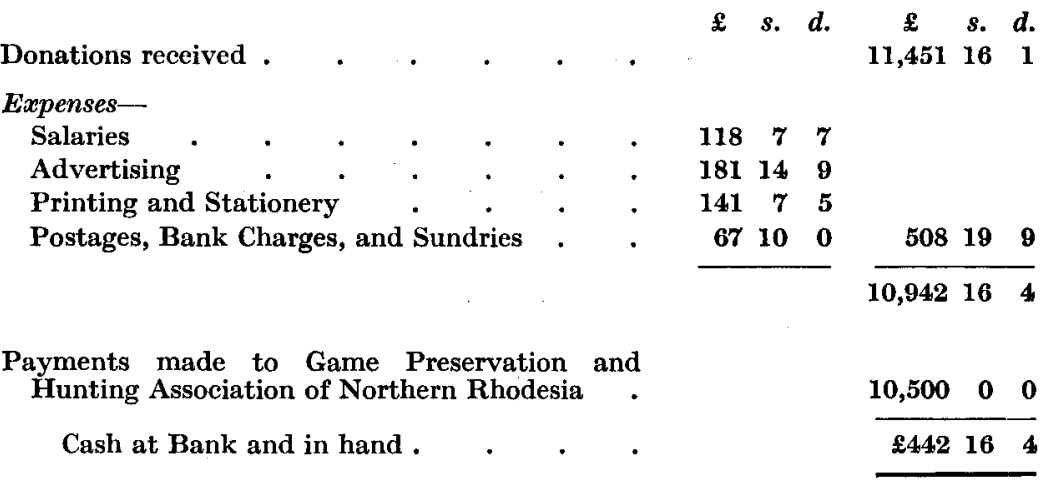

We have examined the above Receipts and Payments Account with the books and accounts of the Fund, and certify it to be in accordance therewith.

We have verified the Cash balance.

Finsaury Circus House,

W. B. KEEN \& CO.,

Blomfield Street,

Chartered Accountants.

LoNDON, E.C. 2.

17 th February, 1960. 
ANNUAL GENERAL MEETING, 1960

The Annual General Meeting will be held at the Offices of the Zoological Society of London, Regent's Park, N.W. 1, on Tuesday, 26th April, 1960, at 5 p.m.

The Marquess of Willingdon, President, in the Chair.

Tea may be obtained at the Fellows' Restaurant before the Meeting.

\section{Agenda}

(1) Reading and confirmation of the Minutes of the Annual General Meeting, 1959.

(2) Presentation of the Auditors' Report.

(3) Discussion of the Auditors' Report.

(4) Presentation of the Council's Annual Report.

(5) Discussion of the Council's Annual Report.

(6) Election of Officers of the Society.

(7) Election of members to fill vacancies on the Council.

\section{Notes}

(1) The Auditors' Report and the Council's Annual Report are given on pages 1-10.

(2) The Council recommend that the following shall be elected as officers of the Society for 1960 :-

President : The Marquess of Willingdon.

Honorary Treasurer : I. D. Malcolmson, Esq.

(3) The following members of Council retire on 26th April, 1960 , and are not eligible for re-election for one year :-

Lieut.-Col. G. A. E. Gibbs.

D. R. Rosevear, Esq., C.B.E.

(4) The following have been appointed to fill vacancies on Council and their names are submitted for confirmation :-

Appointed 14th January, 1960 :-

David James, Esq., D.S.C., M.B.E., M.P.

Appointed 26th April, 1960 :-

W. Ameer Ali, Esq., C.I.E., I.C.S. (Retired).

F. F. Darling, Esq., D.Sc., Ph.D., F.R.S.E.

\section{LECTURE}

(To follow immediately after the A.G.M.)

5.30-6.30 p.m. " Endangered Animals of the World." By Lieut.-Col. C. L. Boyle. Illustrated with drawings and maps by Mr, Gene M, Christman, 
Oryx, Volume V, Nos. 4 and 5, are being combined into a special double number which will be published in May, 1960. This will contain a report by Mr. Lee Merriam Talbot, Staff Ecologist of the International Union for Conservation of Nature, 1954-56, on endangered animals of the Middle East and Southern Asia and of the state of nature conservation in those areas. It will be illustrated with drawings and maps by Mr. Gene M. Christman, Staff Illustrator, Museum of Vertebrate Zoology, University of California, and by the author's photographs.

Oryx, Volume V, No. 6, which will complete Volume V, will be published, with index, on 1st October, 1960.

\section{Christmas Cards, 1960}

(An order form is enclosed. Cards can be sent immediately.)

(a) "Caribou and Calf in Northern Canada." A reproduction, $6 \frac{1}{2}$ in. by 5 in., in full colour, of a painting by Maurice Wilson. Price ( $(a)$ with envelopes) $1 s$. each, or $8 s$. a dozen, post free.

(b) "Sable Antelope." 6 in. by $4 \frac{1}{2}$ in., in black and white, by Miss R. Tomkinson.

(c) "Red Lechwe." 5 in. by 4 in., in black and white from a photograph by L. P. Warland.

Price $((b)$ and $(c)$, with envelopes), $6 d$. each, or $5 s .6 d$. a dozen, post free.

Printed inside all cards is :-

$$
\begin{gathered}
\text { With Christmas } \\
\text { and } \\
\text { New Year Greetings } \\
\text { from }
\end{gathered}
$$

If desired the name and address of the sender may be inserted, at an extra charge of :-

For one dozen cards or less 13s. $6 d$.

For every further dozen cards 